\title{
Hematology Profile and Sperm Quality in Mice (Mus musculus) Balb/C Strain Post Vasectomy
}

\section{Nabila Elmiranda ${ }^{1}$, Andi Hiroyuki ${ }^{1,2 *}$, Vanessa Ayu Sumirat ${ }^{3}$, Neni Anggraeni ${ }^{3}$, Alkaustariyah Lubis $^{4}$, Rini Widyastuti ${ }^{4,5}$, Mas Rizky A.A Syamsunarno ${ }^{2,5}$}

${ }^{1}$ Veterinary Study Program, Faculty of Medicine, Universitas Padjadjaran, Jatinangor, Indonesia, 45363; ${ }^{2}$ Department of Biomedical Sciences, Faculty of Medicine, Universitas Padjadjaran, Jatinangor, Indonesia, 45363; ${ }^{3}$ Medical Laboratory Technologist, Bakti Asib School of Analyst, Bandung, 40192, Indonesia; ${ }^{4}$ Laboratory of Animal Reproduction and Artificial Insemination, Department of Animal Production Animal Husbandry Faculty, Universitas Padjadjaran, Jatinangor, Indonesia, 45363; ${ }^{5}$ Central Laboratory, Universitas Padjadjaran, Jatinangor, Indonesia, 45363.

\begin{abstract}
Vasectomy is a male contraceptive method considered effective and safe because it is performed under local anesthesia where ductus deferens end up in ligation through a small scrotal incision. However, the effect of short-term period after vasectomy has not been well studied. This study aimed to determine the effect of short-term period after vasectomy on hematological profile and sperm quality. This study used 13 mice (Mus musculus) BALB/c strains which were divided into two groups, namely control group (Sham) and treatment (vasectomy). After 14 days, blood sampling was performed for hematology profile examination, and spermatozoa had been collected from cauda epididymis for analysis of spermatozoa quality. The results showed that the average value of erythrocyte count, hemoglobin, and hematocrit were significantly increased $21 \%, 14.77 \%$, and $18.28 \%$ respectively in the treatment group, and mean corpuscular hemoglobin $(\mathrm{MCH})$ decreased in the treatment group $(\mathrm{p}<0.05)$. The monocyte percentage parameter was significantly decreased in the treatment group compared to the control group $(\mathrm{p}<0.05)$. An increase in spermatozoa concentration occurred in the treatment group while spermatozoa motility decreased. Changes in hematological values were still within normal limits and there were no health problems. Differences in hematological values are caused by changes in nutrition and stress conditions after vasectomy surgery. In addition, vasectomy caused a decrease in sperm quality in mice.
\end{abstract}

Keywords | Vasectomy, Hematological profile, Spermatozoa quality, Mice, Cauda epididymis

Received | July 01, 2021; Accepted | September 26, 2021; Published | November 15, 2021

*Correspondence | Andi Hiroyuki, Department of Biomedical Sciences, Faculty of Medicine, Universitas Padjadjaran, Bandung Sumedang Street KM 21, Jatinangor-West Java Indonesia, 45363; Email: a.hiroyuki@unpad.ac.id

Citation | Elmiranda N, Hiroyuki A, Sumirat VA, Anggraeni N, Lubis A, Widyastuti R, Syamsunarno MRAA (2021). Hematology profile and sperm quality in mice (Mus musculus) Balb/C strain post vasectomy. Adv. Anim. Vet. Sci. 9(12): 2258-2265.

DOI | http://dx.doi.org/10.17582/journal.aavs/2021/9.12.2258.2265

ISSN (Online) | 2307-8316; ISSN (Print) | 2309-3331

Copyright (C) 2021 Elmiranda et al. This is an open access article distributed under the Creative Commons Attribution License, which permits unrestricted use, distribution, and reproduction in any medium, provided the original work is properly cited.

\section{INTRODUCTION}

$\mathrm{P}$ opulation growth has become a significant public health problem because of its multidimensional consequences (Perrott and Holland, 2005). Vasectomy is a sterilization method that involves cutting or blocking the vas deferens to prevent sperm from mixing with semen. Vasectomy results in ejaculation that does not carry sperm and cannot fertilize an egg (Fainberg and Kashanian, 2018). Although there are various methods of contraception, sterilization shows the most effective results (WHO, 2004). Vasectomy is a very effective and safe method of male contraception and is performed under local anesthesia where the ductus deferens ends in ligation through a small scrotal incision (Shafik, 2000). Currently, more than 100 million men worldwide have used vasectomy for family planning 
purposes (J1, 1997). Vasectomy is also used to control animal populations such as elephants, horses, sheep, pigs, deer, cattle, bison (Vitoria et al., 2019), and birds (Samour, 2010). However, currently, the interest in vasectomy is still low (Labrecque et al., 2005). This reflects the concern that surgery is considered to cause health problems and reduce sexual function (Puri et al., 2000).

In a study on the chronic effects of vasectomy in laboratory animals such as rats, hamsters, and monkeys, the formation of sperm granulomas is either in the area where ligation was applied to the vas deferens or in the cauda epididymis (Bedford, 1976). After vasectomy, semen analysis is periodically performed to evaluate sperm count and motility (Sokal and Labrecque, 2009). In long term, spermatogenic damage can occur to a pressure resulting in a decrease of sperm count (oligospermia) until no sperm is found (azoospermia) (Xiang et al., 2013). However, the effect of short-term period after vasectomy has not been well studied. In addition, there are no reports on studies of the impact on vasectomy on the hematological profile. The presence of metabolic disorders, disease, damage to organ structure or function, the influence of drugs, and stress can be identified with changes in the hematological profile (Iheidioha et al., 2012). Thus, the study aimed to determine the effect of short-term period after vasectomy on hematological profile and sperm quality. This study provides supporting data to see how vasectomy affects the hematological profile and sperm quality.

\section{MATERIALS AND METHODS}

\section{RESEARCH ETHICS}

The study was approved by Committee for Animal Research Ethics, Faculty of Medicine, Universitas Padjadjaran: (Research ethics number: 1326/UN6. KEP/EC/2019).

\section{Animal treatment}

Male mice (Mus musculus) strain BALB/c, with aged eight to nine weeks old and weighed around 30-40 grams were obtained from P.T. Bio Farma, Bandung, West Java, Indonesia. The animal was acclimatized to seven days to adapt to a new environment. All mice were provided food and water ad libitum and caged in room temperature with 12/12 light dark cycle and adequate air circulation. Thirteen mice were divided into two groups, control groups $(n=7)$ and treatment groups $(n=6)$. Anesthesia procedure was conducted before and during surgery. The mice in the treatment group were anesthetized using a combination of ketamine-Xylazine with a mixed formulation of $7 \mathrm{cc}$ aquades, 1.5 cc Ketamine, $1.5 \mathrm{cc}$ Xylazine, then $0.3 \mathrm{ml}$ was injected intraperitoneally, the anesthetized mice were then vasectomy by cutting the mice's vas deferens in two points at once (Bermejo-Alvarez et al., 2014). All mice in both the control and treatment groups were kept for 14 days to analyze the hematological profile and sperm quality before being sacrificed.

\section{SAMPLES COLLECTION}

Mice were fasted for approximately 8-12 hours, and body weight was measured on the last day of treatment. The samples used in this study consisted of blood samples for hematological analysis and spermatozoa collected from the cauda epididymis for analysis of the spermatozoa quality. After the mice lost consciousness, $1-1.5 \mathrm{ml}$ of blood was taken through a heart puncture and transferred to a $10 \%$ EDTA (Ethylenediamine Tetra-Acetic Acid) microtube as an anticoagulant. The testes and epididymis were isolated by removing them from the connective tissue.

\section{HeMATOLOGY ANALYSIS}

The blood profile was analyzed by using a hematology analyzer (Sysmex Automated Hematology Analyzer; Sysmex Corporation, Japan) according to manufactures protocol. The collected data were red blood cell profiles (erythrocyte count, hemoglobin content, hematocrit, mean corpuscular volume (MCV), mean corpuscular hemoglobin $(\mathrm{MCH})$, mean corpuscular hemoglobin concentration (MCHC), red cell distribution width coefficient variation (RDWC), white blood cell profiles (total number of leukocytes, lymphocytes, monocytes, granulocytes, lymphocyte percentage, monocyte percentage, and granulocyte percentage) and platelet profiles (platelet count, platelet crit (PCT), mean platelet volume (MPV) and platelet distribution width coefficient variation (PDWC).

\section{SPERMATOZOA CONCENTRATION}

Spermatozoa collected from the cauda epididymis were then finely chopped in a petri dish containing $1 \mathrm{~mL}$ of normal saline $\mathrm{NaCl}$ solution $0.9 \%$. A total of $10 \mathrm{ml}$ of the mixture was transferred into the hemocytometer and left to settle. Neubauer's haemocytometry was placed under a microscope (Olympus CX 21, Japan) at a magnification of $200 \mathrm{x}$ and followed by calculating sperm concentration (x10 $\mathrm{sperm}$ cells $/ \mathrm{mL}$ ).

\section{SPERMatozoa Motility}

One drop of semen was placed on the object glass and added with one drop of physiological $\mathrm{NaCl}$ solution 0.9 $\%$, then covered with a cover glass. Spermatozoa motility was observed under a microscope at a magnification of 100x (Olympus CX21, Japan). Spermatozoa motility was grouped into categories of fast progressive spermatozoa cells (A), slow progressive (B), not progressive (C), and not motile (D), then calculated simultaneously. Motility percentage was calculated based on the calculation formula as follows:

$$
(A+B) /(A+B+C+D) \times 100 \%
$$




\section{STATISTICAL ANALYSIS}

The parametric independent sample t-Test was conducted to evaluate the differences between control and treatment group. The $\mathrm{P}$-value of $<0.05$ was considered statistically significant. Statistical analysis in this study was assisted by Graph Pad statistics software prism 9.0.

\section{RESULT AND DISCUSSION}

The results of the examination of the hematological profile and sperm quality were statistically processed using the T-test to determine whether there was a significant difference between the control group and the treatment group $(\mathrm{P}<0.05)$. In this study, the authors present the data as the mean \pm standard deviation (SD).

The results of the analysis of the erythrocyte profile with several assessment parameters are presented in Figure 1. The erythrocyte count parameter showed a significant difference between the control and treatment groups $(\mathrm{P}<0.05)$. The mean value of the number of erythrocytes tended to increase in the treatment group compared to the control group [(8.84 \pm 0.93$)$ vs $(7.30 \pm 0.99), \mathrm{P}=0.0082]$. Hemoglobin parameter showed a significant difference between the control and treatment groups $(\mathrm{P}<0.05)$. The mean value of hemoglobin tends to increase in the treatment group compared to the control group $[(14.92 \pm 5.77)$ vs $(13.00 \pm 1.74), \mathrm{P}=0.0390]$. The hematocrit parameter showed a significant difference between the control and treatment groups $(\mathrm{p}<0.05)$ (Figure 1). The mean hematocrit value tended to increase in the treatment group compared to the control group $[(42.19 \pm 3.72)$ vs (35.67 \pm 4.54$), \mathrm{P}=0.0012]$. Parameters mean corpuscular hemoglobin $(\mathrm{MCH})$ showed a significant difference between the control and treatment groups $(\mathrm{p}<0.05$; Figure 1 ). The average $\mathrm{MCH}$ value tended to decrease in the treatment group compared to the control group [(16.88 \pm $0.23)$ vs $(17.83 \pm 0.68), \mathrm{P}=0.0082]$.

The mean values of the erythrocyte count, hemoglobin, and hematocrit increased significantly higher $21 \%, 14.77 \%$, and $18.28 \%$, respectively in the vasectomy treatment group, and the mean corpuscular hemoglobin $(\mathrm{MCH})$ decreased to a lower 5.3\% in the vasectomy treatment group compared to the control group. Parameter analysis mean corpuscular volume (MCV) tended to decrease in the treatment group compared to the control group $[(47.67 \pm 2.16)$ vs $(49.00$ $\pm 2.31),(\mathrm{P}=0.2279)]$. This is similar to the examination carried out on other erythrocyte profile parameters, namely the mean corpuscular hemoglobin concentration (MCHC) which tends to decrease in the treatment group compared to the control group $[(35.38 \pm 1.33)$ vs $(17.83 \pm 0.3368),(\mathrm{P}=0.1911)]$, then the red cell distribution width coefficient variation (RDWC) parameter tends to decrease in the treatment group compared to the control group $[(21.08 \pm 0.88)$ vs $(23.59 \pm 3.33), \mathrm{P}=0,1026]$. There was no significant difference in all groups of mice with parameters $\mathrm{MCV}, \mathrm{MCHC}$ and $\mathrm{RDWC}(\mathrm{P}>0.05)$. This shows that the vasectomy procedure does not affect the parameters of $\mathrm{MCV}, \mathrm{MCHC}$, and $\mathrm{RDWC}$.
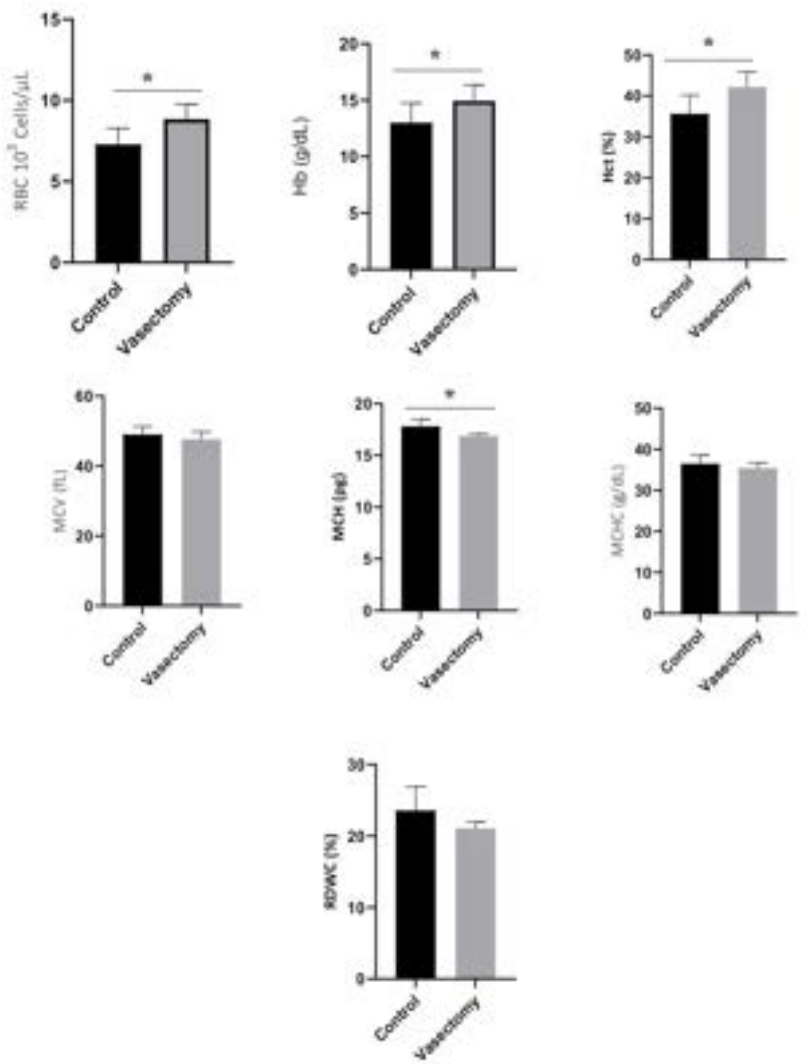

Figure 1: The average value of the red blood cell profile in the control group and the treatment group was measured after 14 days after vasectomy. RBC, Red Blood Cells; Hb, Hemoglobin; Hct, Hematocrit; MCV, Mean Corpuscular Volume; MCH (Mean Corpuscular Hemoglobin; MCHC, Mean Corpuscular Hemoglobin Concentration; RDWC, Red Cell Distribution Width (RDWC). *, $\mathrm{P}<0.05$.

The results of the analysis of the leukocyte profile with several assessment parameters are presented in Figure 2. The leukocyte count parameter tended to decrease in the treatment group compared to the control group [(5118 \pm $2729)$ vs $(7680 \pm 7341),(\mathrm{P}=0.9452)]$. Lymphocyte counts tended to decrease in the treatment group compared to the control group $[(3417 \pm 2803)$ vs $(4801 \pm 5837)$, $\mathrm{P}=0.7308]$. The number of monocytes tended to increase in the treatment group compared to the control group $[(405.0 \pm 341.5)$ vs $(1713 \pm 1852), P=0.1014]$. The number of granulocytes tended to increase in the treatment group compared to the control group [(1290 \pm 774.0$)$ vs $(1164 \pm$ $650.2), \mathrm{P}=0.7560)$. The percentage of lymphocytes tended to increase in the treatment group compared to the control group $[(61.64 \pm 17.18)$ vs $(61.64 \pm 17.18), \mathrm{P}=0.2741]$. 
The percentage of the number of granulocytes tended to increase in the treatment group compared to the control group [(1290 \pm 774.0$)$ vs $(1164 \pm 650.2), \mathrm{P}=0.7712]$. This indicates that the vasectomy procedure did not affect the leukocyte profile parameters $(P>0.05)$. A significant difference between the control and treatment groups $(\mathrm{p}<0.05)$, was found in the percentage of monocytes $(\mathrm{P}=0.0406)$. The percentage of monocytes tended to decrease in the treatment group compared to the control group $[(7.650 \pm 3,261)$ vs $(24.09 \pm 16.98)]$.
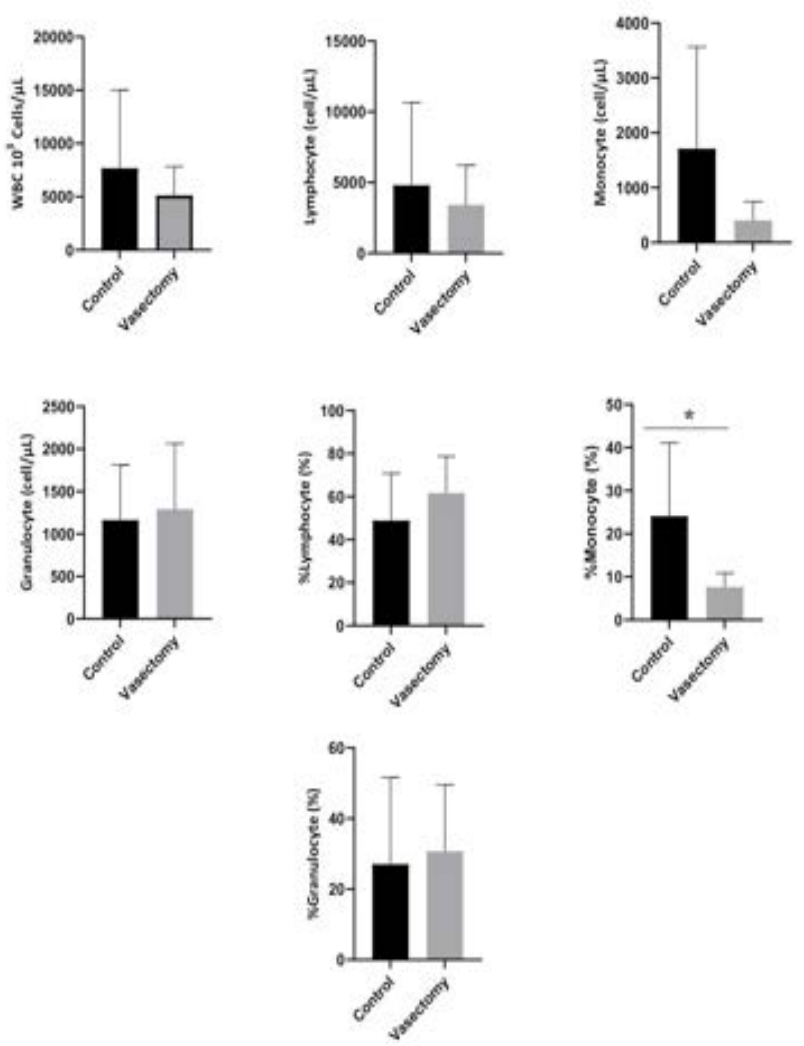

Figure 2: The average value of the white blood cell profile in the control group and the treatment group was measured after 14 days after vasectomy. WBC, White Blood Cells; *, $\mathrm{P}<0.05$.

The results of the analysis of the platelet profile with several assessment parameters are presented in Figure 3. The platelet profile consists of several parameters, namely the number of platelets, plateletcrit (Pct), mean platelet volume (MPV), and platelet distribution width coefficient variation (PDWC) significant between the control group and the treatment group $(\mathrm{P}>0.05)$. Platelet count $[(574667 \pm 123262)$ vs $(564571 \pm 1974), \mathrm{P}=0.9158]$. Parameters Pct $[(0.23 \pm 0.07)$ vs. $(0.20 \pm 0.07), \mathrm{p}=0.4972]$, $\operatorname{MPV}[(3.967 \pm 0.6022)$ vs $(3.743 \pm 0.6051), \mathrm{P}=0.5190)$ and PDW $[(34.00 \pm 1.221)$ vs $(33.50 \pm 1.770)$ tended to show a mean value that the same in both the treatment group and the control group.
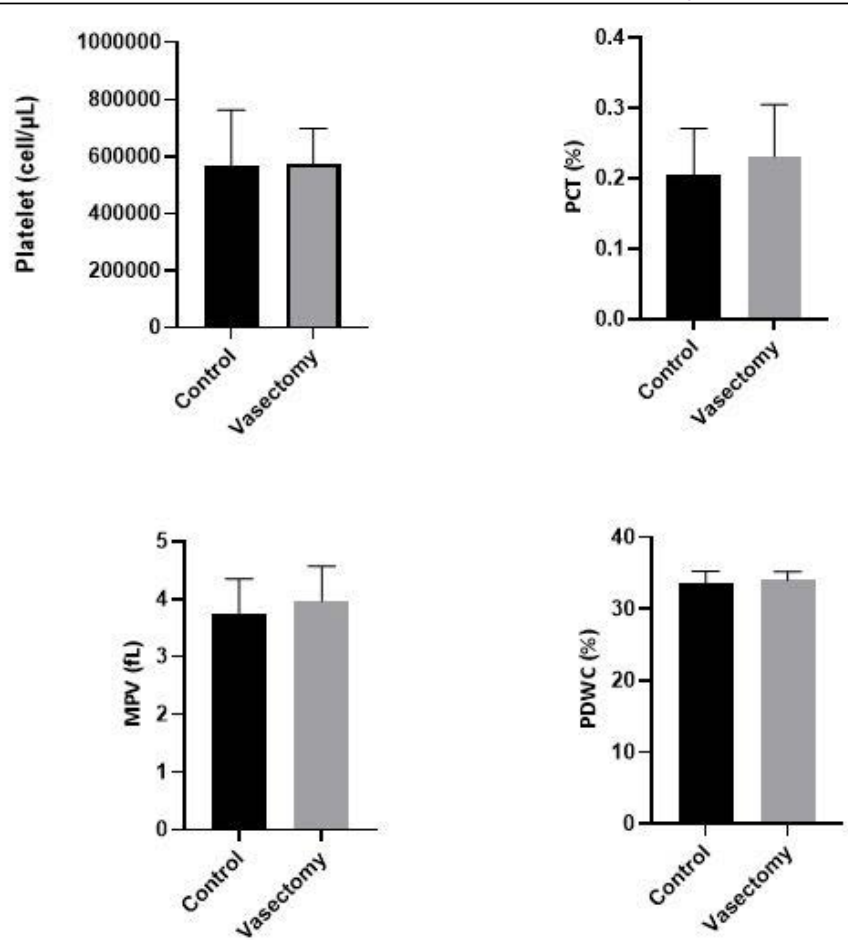

Figure 3: The average value of the platelet profile in the control group and the treatment group was measured after 14 days after vasectomy. All parameters tend to show the same average value in both the control and treatment groups. PCT, Platelet; MPV, Mean Platelet Volume; PDWC, Platelet Cells Distribution Width.
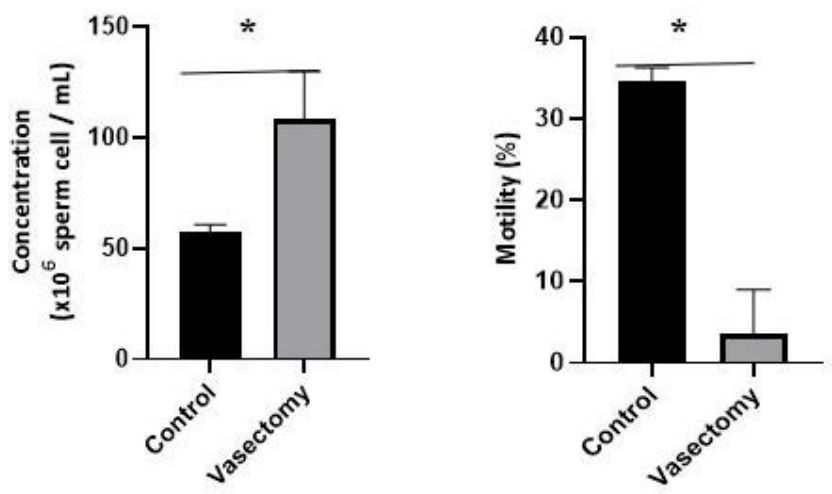

Figure 4: The average value of sperm concentration and sperm motility in the control and treatment groups after 14 days after vasectomy. ${ }^{*}, \mathrm{p}<0.05$.

The results of the analysis of sperm quality with parameters for assessing sperm concentration and sperm motility are presented in Figure 4. Overall sperm quality parameters showed a significant difference between the control and treatment groups $(\mathrm{P}<0.05)$. Parameters of sperm concentration tended to increase in the treatment group compared to the control group [ $(108.5 \pm 21.36)$ vs $(57.57$ $\pm 3.259), \mathrm{P}=0.0001]$. Sperm motility parameters tended to decrease in the treatment group compared to the control group [(3500 \pm 5.505$)$ vs $(34.57 \pm 1.718), \mathrm{P}=0.0012]$.

The vasectomy method is preferred more than the 
castration method, which are considered more complicated, time-consuming, and requires intensive postoperative care in animals (Dhanlakshmi et al., 2007). However, the short-term effect of this method is considered to affect health conditions and sexual function (Puri et al., 2000). In this study, vasectomy showed changes in hematological assessment, where the vasectomy procedure caused a decrease in the parameters of erythrocyte count, hemoglobin, hematocrit, and mean corpuscular hemoglobin $(\mathrm{MCH})$. The vasectomy procedure in this study had a positive impact because based on the results of the study showed that the vasectomy procedure did not cause blood and health problems, changes in the hematological profile that occurred in this study were thought to be caused by several factors. such as nutrition and stressful conditions due to the application of vasectomy. vasectomy procedures in mice.

The results showed that the number of erythrocytes increased in the treatment group compared to the control group. The increase in the number of erythrocytes in the treatment group can be caused by various factors, one of which is stress conditions, this is supported by research by Mariotti (2015) which states that stress conditions can cause various adverse effects on the body system, especially the immune system and hematopoiesis (Mariotti, 2015). Mice that received treatment tended to experience higher stress than the control group, stress conditions that occurred in the treatment group could be caused by discomfort due to the response to pain and swelling of the post-vasectomy wound (Leach et al., 2012). Physiologically, stressful conditions activate the hypothalamus, which controls two neuro-endocrine systems, namely the sympathetic and adrenal cortex systems. The sympathetic nervous system will signal the adrenal medulla to release the hormones epinephrine and norepinephrine into the bloodstream, which can cause the increase of heart rate, the improve the blood flow to muscles, and oxygen demand to increase. These conditions can be the cause of accelerated erythropoiesis in bone marrow. However, the increase in the number of erythrocytes in this study did not indicate a blood disorder (polycythemia) because the number of erythrocytes was still in normal range of $6.89-11.7106 / \mu \mathrm{L}$ (Heryanita et al., 2018).

The results showed that the average value of hemoglobin in the treatment group tended to be higher than the control group. The hemoglobin level depends on the number of erythrocytes. If the erythrocyte count is high, the hemoglobin will be high and vice versa. This is in line with the results of research showing an increase in the number of erythrocytes, so that the hemoglobin value will also increase. An increase in hemoglobin level in the blood that exceeds the upper limit of the normal range is called polycythemia (Norsia, 2015). The hemoglobin value in mice can be influenced by several factors such as age, nutrition, and animal health conditions (Smith and Jarecki, 2011). Unbalanced nutrition can affect the physiological condition of the animal's body, if the animal's body undergoes physiological changes, the blood components will also experience changes (Guyton, 1995). Unbalanced nutritional conditions can cause physiological changes in the body of mice, where pain due to incisions and suturing due to vasectomy surgery is thought to affect the nutritional status of mice (Leach et al., 2012). The average hemoglobin value of mice in this study was still in normal range, and this is in line with previous studies, where the hemoglobin value of normal mice was in the field of 12.79-15.90 g/dl (Benkovic et al., 2012; Osanaiye et al., 2015), so it can be stated that this vasectomy procedure does not cause health problems or disturbances in hemoglobin.

The results showed that the hematocrit value in the treatment group tended to be higher than the control group. Hematocrit on treatment can be increased due to dehydration and stress conditions. Mice in the treatment group will tend to experience higher stress than the control group, the stress that occurs can trigger an increase in pain or after vasectomy surgery. This situation causes the high concentration of erythrocytes in the spleen to be high. This is supported by research conducted by Robergs (1997) which states that when animals experience stress, the hormone epinephrine will increase spleen contraction so that red blood cells in the blood circulation become more numerous and ultimately increase the hematocrit value. The value of hematocrit in healthy animals is that normal animals have a hematocrit value that is proportional to the number of erythrocytes and hemoglobin levels. The same thing was found in this study, where a rise followed an increase in the hematocrit value in the number of erythrocytes and hemoglobin. The increase of hematocrit values in the treatment group did not indicate a blood disorder because the hematocrit value in this study was still within the normal range of hematocrit in mice, namely 33.1-49.9\% (Kusmawati, 2004).

The results showed that the average $\mathrm{MCH}$ value decreased in the treatment group compared to the control group. A decrease in the $\mathrm{MCH}$ value may indicate that the individual has hypochromic microcytic anemia (Gandasoebrata, 2013). This type of anemia can be caused by several factors, one of which is low iron intake. Vasectomy surgery is possible to affect the nutritional status of mice, where pain due to incisions and suturing can occur after vasectomy surgery (Leach et al., 2012) so that during the 14-day postoperative maintenance, the mice chose to focus on pain compared to the feed that should have been maximally fulfilled for the nutritional needs of the mice, causing a decrease in appetite and automatically imbalanced nutrition in mice. The dietary components 
contained in the feed used to compose the formation of $\mathrm{MCH}$ are $\mathrm{Fe}$ (iron) and protein (Saputro and Junaidi, 2015). Other erythrocyte profile parameters such as $\mathrm{MCV}, \mathrm{MCHC}$, and RDWC did not show any significant difference between the control and treatment groups. This reflects that statistically the vasectomy procedure does not affect the number of erythrocytes.

The results of this study showed that the leukocyte profile with the parameter of monocyte proportion showed a decrease in the treatment group compared. Leukocytes are one of the body's defense compartments. A substantial reduction in the proportion of monocytes occurred in mice in the treatment group. The level of monocytes decreased significantly after receiving treatment in the form of vasectomy surgery. Monocytopenia or decreased monocyte percentage can be both physiological and pathological. Physiological monocytopenia occurs in the early stages of stress (due to the vasectomy procedure), whereas pathological monocytopenia occurs after the acute phase of the disease ends (Preanger et al., 2016). The percentage of monocytes in the control group and shows an abnormal range, this is supported by previous studies which state that the normal range of monocytes in mice is in the range of 0.1-3.5\% (Clauss et al., 2012; Fahrimal et al., 2014). The difference in the percentage of monocytes in this study was due to the absence of infection, according to the study of Utami et al. (2013) the decrease in the proportion of monocytes is related to the function of monocytes themselves, namely as macrophages, where monocytes are not really needed for phagocytosis because there is no infection that enters the body that triggers monocyte production.

Unlike the case with examining all components of the platelet profile, which statistically did not show any significant differences between the control and treatment groups. The average value of all parameters of the platelet profile tends to offer the same average value in both control and treatment groups. Platelets serve as the first line of defense against bleeding, contributing to the process of thrombosis, neoplasia, and inflammation (Holinstat, 2017). Changes in platelet values can be caused by several factors such as blood collection procedures and techniques, the effect of anticoagulants, and storage conditions for test samples (Cora et al., 2012; Rosidah et al., 2020; Fitria et al., 2016). Platelets serve as the first line of defense against bleeding, contributing to the process of thrombosis, neoplasia, and inflammation (Holinstat, 2017). In this case, the vasectomy procedure does not affect to the platelet count.

In addition to affecting the hematological profile, the application of the vasectomy procedure for 14 days in this study was found to have a significant effect on sperm quality.
Sperm concentration is the number of spermatozoa obtained in one storage. The assessment of spermatozoa concentration is an essential factor that describes the characteristics of sperm used as one of the criteria for determining semen quality. Sperm concentration can be influenced by several factors, including sexual development, feed quality, reproductive health, testicular size, age, and frequency of male ejaculation (Salisbury and Van Demark, 1985). In this study, sperm motility in the vasectomy treatment group decreased up to $89,87 \%$ compared to the control group. This indicates that the vasectomy procedure reduces sperm motility in vasectomy rats (Longquan et al., 2011). Sperm motility is related to fertility, where sperm motility is essential for efficient penetration (Farrell et al., 1998; Fetterolf and Roger, 1990). Based on research that has been done, protein plays a critical role in spermatozoa maturation and sperm function at the site of fertilization. Vasectomy significantly reduces the concentration of significant proteins) cysteine-rich secretory protein (CRISP-1), minor protein, phosphatidylethanolamine-binding protein, and prostaglandin D2 (Turner et al., 1999, 2000).

Furthermore, a study demonstrated that applying a 14day vasectomy procedure could alter the synthesis overall epididymal protein, including CRISP-1 synthesis and secretion (Turner et al., 1999). Therefore, persistent changes in epididymal protein synthesis and secretion may alter the sperm maturation process and affect male fertility. This suggests the application of contraceptive methods. In this study, the vasectomy method of contraception showed an effect on fertility which was indicated by a decrease in the percentage of sperm motility.

The conclusions in this study indicate that the changes in hematological values in this study were still within normal limits and there were no health problems, the difference in the average values for each parameter was thought to be caused by several factors such as nutrition and stress conditions, therefore the application of the vasectomy procedure could be improved. through good and correct pain management and postoperative management in mice. In addition, the application of the vasectomy procedure affected sperm quality as indicated by an increase in sperm concentration and a decrease in sperm motility in the treatment group compared to the control group.

\section{ACKNOWLEDGEMENTS}

This study was supported by Research grant from Ministry of Education, Culture, Research and Technology Republic of Indonesia.

\section{NOVELTY STATEMENT}

To the best of our knowledge, this is the first report to 
conduct a study using mice (Mus musculus) of the Balb/C strain to determine its effect on hematological profiles and sperm quality.

\section{AUTHOR'S CONTRIBUTION}

All authors design and performing experiment. NE, MRAAS, AH, performed data analysis, interpretation, and literature. All of the author preparing and writing the manuscript.

\section{CONFLICT OF INTEREST}

The authors have declared no conflict of interest.

\section{REFERENCES}

-Aku A, Srimarsina S, Takdir S (2009). Effect of testis and cauda epididymis on sperm concentration in Bali cattle.

-Bedford JM (1976). Adaptations of the male reproductive tract and the fate of spermatozoa following vasectomy in the rabbit, rhesus monkey, hamster and rat. Biol. Reprod., 14(2): 118-142. https://doi.org/10.1095/biolreprod14.2.118

-Benkovic V, D Dikic, T Grgorinic, M Mladinic, DZ Eljezic (2012). Haematology and Blood Chemistry Changes in Mice Treated with Terbuthylazine and its Formulation Radazin TZ-50. Bull Environ. Contam. Toxicol. 89: 955959.

-Bermejo-Alvarez P, Park KE, Telugu BP (2014). Utero-tubal embryo transfer and vasectomy in the mouse model. J. Visual. Exp., pp. 84. https://doi.org/10.3791/51214

- Clauss M (2012). Clinical technique: Feeding hay to rabbits and rodents. J. Exot. Pet Med., 21(1): 80-86. https://doi. org/10.1053/j.jepm.2011.11.005

- Cora MC, King D, Betz LJ, Wilson R, Travlos GS (2012). Artifactual changes in sprague-dawley rat hematologic parameters after storage of samples at $3 \mathrm{C}$ and $21 \mathrm{C}$. J. Am. Assoc. Lab. Anim. Sci., 51(5): 616-621.

-Dhanlakshmi S, Jayasimha, Nanjappa KA (2007). Mass vasectomy in black bucks (Antilope cervicapra). Zoos Print J., 22(11): 2895-2896. https://doi.org/10.11609/JoTT. ZPJ.1759.2895-6

- Fahrimal Y, Eliawardani E, Rafina A, Azhar A, Asmilia N (2014). Blood profile of white rats (Rattus norvegicus) infected with Trypanosoma evansi and Given Jaloh Bark Extract (Salix tetrasperma Roxb). J. Vet. Med. Indonesian J. Vet. Sci., 8(2).

- Fainberg J, Kashanian JA (2018). Vasectomy. J. Am. Med. Assoc., 319(23): 2450-2450. https://doi.org/10.1001/ jama.2018.6514

- Farrell PB, Presicce GA, Brockett CC, Foote RH (1998). Quantification of bull sperm characteristics measured by computer-assisted sperm analysis (CASA) and the relationship to fertility. Theriogenology, 49(4): 871-879. https://doi.org/10.1016/S0093-691X(98)00036-3

- Fetterolf PM, Rogers BJ (1990). Prediction of human sperm penetrating ability using computerized motion parameters. Mol. Reprod. Dev., 27(4): 326-331. https://doi. org $/ 10.1002 / \mathrm{mrd} .1080270406$

- Fitria L, Illiy LL, Dewi IR (2016). Pengaruh antikoagulan dan waktu penyimpanan terhadap profil hematologis tikus
(Rattus norvegicus Berkenhout, 1769) galur wistar. Biosfera. 33:22-30. https://doi.org/10.20884/1.mib.2016.33.1.321

-Fitria L, Illiy LL, Dewi IR (2017). Effect of anticoagulant and storage time on the hematological profile of rats (Rattus norvegicus Berkenhout, 1769) wistar strain. Biosph. Biol. Sci. Mag. A Sci. J., 33(1): 22-30. https://doi.org/10.20884/1. mib.2016.33.1.321

- Gandasoebrata R (2013). Technical Laboratory Guide. Jakarta. Dian Rakyat

- Guyton CA (1995). Textbook of medical physiology. $7^{\text {th }}$ edition. EG, Jakarta. Hut, F.B. 1964. Animal Genetics. John Willey and Sons, New York.

- Heryanita Y, Rusli R, Rosmaidar R, Zuraidawati Z, Rinidar R, Asmilia N, Jalaluddin M (2018). 4. Values of erythrocytes, hemoglobin, and hematocrit of mice (Mus musculus) exposed to cigarette smoke and given red watermelon extract (Citrullus vulgaris). J. Vet. Med., 12(1): 24-31. https://doi. org/10.21157/j.med.vet..v12i1.4106

- Holinstat M (2017). Normal platelet function. Cancer Metast. Rev., 36(2): 195-198. https://doi.org/10.1007/s10555-0179677-x

-Ihedioha JI, Ugwuja JI, Noel-Uneke OA, Udeani IJ, DanielIgwe $G$ (2012). Reference values for the haemotology profile of conventional grade outbred albino mice (Mus musculus) in Nsukka, Eastern Nigeria. Anim. Res. Int., 9(2).

-J1 GB (1997). No-scalpel vasectomy: review of the first 1,000 cases in a family medicine unit. Arch. Med. Res., 28(4): 517-522.

-Kusmawati D (2004). Friendly with Experimental Animals. Gadjah Mada University Press. Yogyakarta.

-Labrecque M, Pile J, Sokal D, Kaza RC, Rahman M, Bodh SS, Vaidya TM (2005). Vasectomy surgical technique in South and Southeast Asia. BMC Urol., 5(1): 1-9. https://doi. org/10.1186/1471-2490-5-10

- Leach MC, Klaus K, Miller AL, Scotto di Perrotolo M, Sotocinal SG, Flecknell PA (2012). The assessment of post-vasectomy pain in mice using behaviour and the Mouse Grimace Scale. PLoS One, 7(4): e35656. https://doi.org/10.1371/journal. pone. 0035656

- Longquan Ren, Qiang Weng, Miori Kishimoto, Gen Watanabe, Sukanya Jaroenporn, Kazuyoshi Taya. (2011). Effect of Short Period Vasectomy on FSH, LH, Inhibin and Testosteron Secretions, and Sperm Motility in Adult Male Rats. Tokyo Univ. Agric. Technol.

- Mariotti A (2015). The effects of chronic stress on health: new insights into the molecular mechanisms of brainbody communication. Future Sci. OA, 1(3). https://doi. org/10.4155/fso.15.21

- Matida ET, Zancanaro AE, Restel TI, Gomes WMW, Bazzano T, Mori CMC, Teixeira MA (2015). Determination of biochemical a hematological parameter in mice (Mus musculus) from the UFMS central vivarium. Rev. Soc. Bras. Cienc. Anim. Lab., 3: 30-35.

- Norsia W (2015). Differences in Hemoglobin Levels Cyanmethemoglobin Method with and Without Centrifugation on Leukocytosis Samples. J. Med. Laborat. Technol. 1(2): 72-83.

- Osanaiye BC,A.J Nok, E Amlabu, E Haruna (2015).Assessment of Changed in Serum Haematological Parameters in the Plasmodium berghei Infected Albino Mice Treated with Neem (Azadirachta indica) Extracts. Int. J. Chem. Biomolecul. Sci. 1(3): 148-152.

-Perrott GSJ, Holland DF (2005). Population trends and 
problems of public health. The Milbank Quart., 83(4): 569. https://doi.org/10.1111/j.1468-0009.2005.00393.x

- Preanger C, Utama IH, Kardena IM (2016). An overview of catfish blood smears in Denpasar Bali. Indonesia Medicus Veterinus, 5(2): 96-103.

-Puri CP, Gopalkrishnan K, Iyer KS (2000). Constraints in the development of contraceptives for men. Asian J. Androl., 2(3): 179-190.

-Ren L, Weng Q, Kishimoto M, Watanabe G, Jaroenporn S, Taya K (2011). Effect of short period vasectomy on FSH, $\mathrm{LH}$, inhibin and testosterone secretions, and sperm motility in adult male rats. Exp. Anim., 60(1): 47-56. https://doi. org/10.1538/expanim.60.47

- Robergs R (1997). Exercise Physiology. Missouri, USA. Mosby Year Book, Inc.

-Rosidah I, Ningsih S, Renggani TN, Efendi J, Agustini K (2020). Hematological profile of rats (Rattus norvegicus) sprague-dawley strain male 7 and 10 weeks age. Indonesian J. Biotechnol. Biosci., 7(1): 136â-145. https://doi. org/10.29122/jbbi.v7i1.3568

- Salisbury GW (1984). Physiology of reproduction and artificial insemination in cattle. Gadjah Mada Univ. Press.

- Salisbury GW, Vandemark NL (1985). Reproductive Physiology and Artificial Insemination in Cattle. Gajah Mada University Press. Yogyakarta.

-Samour J (2010). Vasectomy in birds: A review. J. Avian Med. Surg., pp. 169-173. https://doi.org/10.1647/2009-024.1

- Saputro DA, Junaidi S (2015). Giving vitamin C to maximum physical exercise and changes in hemoglobin levels and erythrocyte counts. J. Sport Sci. Fitness, 4(3).

-Shafik A (2000). Advances in male contraception. Arch. Androl., 45(3): 155-167. https://doi. org/10.1080/01485010050193931

- Smith C, Jarecki A (2011) Atlas of comparative diagnostic and experimental hematology. 2nd Edition. Wiley-Blackwell, Hong Kong. doi: 10.1002/9781118785072

- Sokal DC, Labrecque M (2009). Effectiveness of vasectomy techniques. Urol. Clin., 36(3): 317-329. https://doi. org/10.1016/j.ucl.2009.05.008

- Tethool AN, Purwaningsih P (2019). Effects of administration of Akway wood extract (Drymis Sp.) on spermatozoa quality of mice (Mus musculus L). J. Trop. Anim. Vet. Sci., 9(1): 24. https://doi.org/10.30862/jipvet.v9i1.8

- Turner TT, Reley T, Mruk DD, Cheng CY (1999). Obstruction of the vas deferens alters protein secretion by the rat caput epididymidal epithelium in vivo. J. Androl., 20(2): 289-297.

-Turner TT, Riley TA, Vagnetti M, Flickinger CJ, Caldwell JA, Hunt DF (2000). Postvasectomy alterations in protein synthesis and secretion in the rat caput epididymidis are not repaired after vasovasostomy. J. Androl., 21(2): 276-290.

-Utami DT, Prayitno SB, Hastuti S, Santika A (2013).Description of hematological parameters in tilapia (Oreochromis niloticus) given different doses of Streptococcus iniae DNA vaccine. J. Aquacult. Manage. Technol., pp. 7-20.

-Vitoria A, Romero A, Fuente S, Barrachina L, Vazquez FJ (2019). Application of a laparoscopic technique for vasectomy in standing horses. Vet. Rec., 185(11): 345-345. https://doi.org/10.1136/vr.105396

-World Health Organization. (2004). Contraception in adolescence.

-Xiang Y, Luo P, Cao Y, Yang ZW (2013). Long-term effect of vasectomy on spermatogenesis in men: A morphometric study. Asian J. Androl., 15(3): 434. https://doi.org/10.1038/ aja.2012.154 